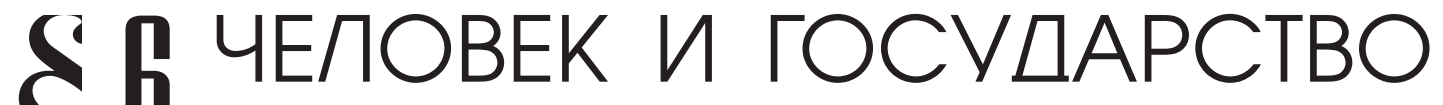

Кокотова М.А

\section{ЦЕННОСТНЫЕ ОСНОВАНИЯ ПРОВЕРКИ КОНСТИТУЦИОННОСТИ ЗАКОНОВ ПО ОБРАЩЕНИЯМ ГРАЖДАН ВО ФРАНЦИИ И РОССИИ}

\begin{abstract}
Аннотация: Предметом исследования является последующий конкретный конституционный контроль по обращениям граждан в Конституционном совете Франиии и Конституционном Суде Российской Федерации. Цель работы - выявить специфику конституционного контроля по обращениям граждан с точки зрения его доктринальных и ценностных оснований. В этом качестве рассматриваются понятия «права человека» и «общий (публичный) интерес», их понимание в практике рассматриваемых органов и доктрине. Особое внимание уделяется ценностям, которые выражают данные понятия. Также анализируется соотношение этих понятий. Основным для работы является аксиологический метод. Также используется метод индукиии. В работе приводится обобщение судебной практики. Новизна исследования заключается в применении аксиологического подхода к рассмотрению последующего контроля. Автор делает вывод о том, что специфика последующего контроля по обращениям граждан заключается в подходе, при котором в разбирательстве присутствует частный интерес. При этом органы конституциионного контроля ищут баланс между защитой прав человека и общего интереса, которые, одновременно, являются ценностными категориями.
\end{abstract}

Ключевые слова: Права человека, частный интерес, обращения граждан, последующий конституционный контроль, Конституциионый Суд России, Конституционный совет Франции, всеобщая воля, общий интерес, ценности, соииальные права.

Abstract: The subject of this research is the specific constitutional control on complaints of the citizens in the Constitutional Council of France and Constitutional Court of Russia. The purpose of this work is to determine the specific aspects of constitutional control with regards to citizens' complaints from the perspective of its doctrinal and value bases. In this context, a review is made of the notions such as "human rights" and "general (public) interest" and their meaning within the practice of the reviewed branches and doctrine. A special attention is given to the values that express these notions, as well as the analysis to the correlation of these notions. The author concludes that specificity of the subsequent control on the citizens' complaints consists in the approach, which involves private interest into the argument. At the same time, the branches of constitutional control are searching for a balance between protection of human rights and public interest, both of which simultaneously represent value categories.

Keywords: Human rights, private interest, citizen complaint, subsequent constitutional control, Constitutional Council of France, Constitutional Court of Russia, public will, public interest, values, social rights.

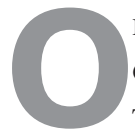

писывая практику осуществления конституционного контроля в разных странах, исследователи выделяют различные его виды (предварительный и последующий, конкретный и абстрактный, обязательный и факультативный, постановляющий и консультативный, централизованный и диффузный [1, С. 169-172; 2, С. 39-41; 3, С. 306]). Предметом настоящего исследования является последующий конкретный контроль законов по обращениям граждан. Последующий контроль заключается в проверке действующих правовых актов, в отличие от предварительного контроля, который на- правлен на проверку конституционности законопроектов или уже принятых законов, но еще не подписанных (промульгированных) главой государства. Такой контроль, по сути, является частью законодательной процедуры.

Конкретный нормоконтроль направлен на проверку нормативных положений в той части, в какой они были применены (или подлежат применению) в конкретном деле. Таким делом может являться судебное дело. Абстрактный же контроль предполагает рассмотрение нормы не в связи с ее применением в правоприменительном, например, судебном деле. 
Последующий конкретный нормоконтроль может осуществляться по обращениям частных лиц или иных субъектов, в частности, судов. Проверка конституционности по обращениям частных лиц и их объединений отличается от иных видов последующего конкретного контроля особой ролью конституционного контроля как способа защиты гражданами своих прав и наличием необходимости учитывать процессуальные права граждан при рассмотрении дел. Кроме того, следует отметить, что граждане составляют самую многочисленную группу из всех субъектов, уполномоченных направлять обращения в орган конституционного контроля.

Если в России введение конституционного контроля по обращениям граждан совпадает по времени с созданием Конституционного Суда, то во Франции данный вид контроля осуществляется только с 2010 г. Его введение означало появление и существенное расширение указанного подхода. Данный процесс можно охарактеризовать как тенденцию к усилению защиты прав и свобод граждан относительно других функций Конституционного совета.

Сущность рассматриваемого подхода состоит не в самом факте предоставления гражданам права обращения за проверкой конституционности закона. Так, во Франции они имеют его и в рамках предварительного абстрактного контроля. Любое физическое или юридическое лицо, заинтересованное в разрешении вопроса о конституционности закона, проверяемого в порядке предварительного контроля, может представить в Конституционный совет свои соображения. Хотя Совет не обязан отвечать на эти соображения, он может использовать содержащуюся в них полезную информацию [4]. Тем не менее, такое предоставление соображений нельзя считать отдельным видом обращений, поскольку они не инициируют конституционный процесс и не требуют принятия отдельных решений.

Конкретный контроль по обращениям граждан также ни в Конституционном Суде России, ни в Конституционном совете Франции не является единственным способом защиты прав человека. Как считают исследователи, на защиту прав человека направлена реализация всех полномочий органов конституционного контроля, связанных как с конституционным нормоконтролем, так и с разрешением споров о компетенции между органами власти, толкованием конституционных положений и др [5, С. 58]. Что касается Конституционного совета, то проверка соответствия законов положениям Конституции о правах человека уже входила в его полномочия до 2010 г.
Специфика конкретного контроля по обращениям граждан состоит в наличии самого подхода контроля, при котором основанием для рассмотрения дела является факт правоприменения (прошлый или предстоящий), задевающий конституционные права и свободы гражданина и в силу этого побуждающий его отстаивать в процедуре конституционного контроля в качестве стороны свой личный интерес. Субъекты, управомоченные обращаться в Конституционный совет, осуществляли это право как часть своей служебной деятельности, а не как способ защиты своего личного интереса. Если обращения, подаваемые органами государственной власти, являются политизированными [6, С. 79], будучи средством парламентской борьбы, то граждане обращаются в орган конституционного контроля для защиты своих прав.

Ведь можно сказать, что между конкретным и абстрактным конституционным контролем существует такая же разница, как между судебными прениями и парламентскими дебатами. Если в суде сталкиваются частные интересы, то в парламенте - варианты решения вопроса, защищаемые разными партиями. Конечно, и в парламенте может защищаться частный интерес, например, путем лоббирования, даже узаконенного, как в Великобритании, но это скорее исключение, не отвечающее сути парламентской деятельности так, как она понимается в России и во Франции. В результате возрастает роль частных субъектов в Конституционном совете Франции, в силу чего он приближается к Конституционному Суду России.

Данная специфика делает интересным изучение доктринальных и ценностных оснований последующего контроля по обращениям граждан. С ним связаны две ценностные категории: права человека и общий интерес. Описываемый подход, очевидно, способствует усилению защиты прав человека, но встает вопрос о том, не ведет ли он к обесцениванию защите общего интереса [7, С. 368]. Так, К. В. Карпенко указывает, что «некоторые решения КС Франции, принятые в рамках новой процедуры, показывают, что отныне свобода всех может ущемляться в угоду свободе каждого» [8, С. 781].

Да и самому введению конституционного контроля в течение длительного времени препятствовала, в том числе, теория парламентского суверенитета во Франции, и теория всевластия советов в России. Общим в этих теориях является представление о недопустимости ограничения власти представителей народа, непосредственно выражающих «всеобщую волю», профессиональными управленцами, судьями. Конкретный контроль по обращениям граждан еще в 
DOI: $10.7256 / 1811-9018.2015 .4 .14689$

При цитировании этой статьи сноска на доі обязательна

\section{Право и политика 4 (184) 2015}

большей степени, чем другие виды контроля, является таким ограничением.

При этом, понятие «всеобщая воля», очевидно, не объяснимо рационально. Не ясно, что она представляет собой, на основании чего делается вывод о том, что такая воля вообще существует, а ведь это совсем не очевидно. Также непонятно, почему народная воля так непогрешима. Скорее можно согласиться с точкой зрения, в соответствии с которой «нет никаких оснований полагать, что в любой социальной структуре, в том числе и в государственно-организованном обществе определенно выраженная воля большинства, или даже единогласие всех граждан, обуславливает справедливость вынесенного решения» [9, С. 7].

Приверженность всеобщей воле можно объяснить тем, что суверенитет парламента основан на нравственных представлениях, которые по своей природе не требуют рационального обоснования. Конечно, это не является особенностью именно данного понятия. Как указывает М. Вебер, «смысл мироздания не раскрывается исследованием, каким бы совершенным оно ни было...мы сами призваны создать этот смысл, ... «мировоззрения» никогда не могут быть продуктом развивающего опытного знания» [10, С. 276]. Институты конституционного права являются способом реализации определенных ценностей, прежде всего тех, которые были выработаны просветителями. Например, избирательные системы с многообразными способами подсчета голосов, формулами для определения квот нужны только потому, что мы признаем ценность народовластия; необходимость в уполномоченном по правам человека существует только при признании ценности самих этих прав. Сказанное, конечно, не означает, что каждому правовому институту всегда и везде соответствует какая-то определенная ценность. Очевидно, что его назначение может изменяться в пространстве и времени. Так, например, институт омбудсмена изначально был создан для контроля за правительством, и лишь затем акцент был сделан на защиту прав человека; с помощью разных концепций обосновывается необходимость существования верхней палаты парламента. Кроме этого, можно предположить, что изменение ценностного основания правового института может и не найти отражения в доктрине.

Во Франции верховенство, ранее принадлежавшее монарху, после Революции было признано за абстрактной «общей волей», представляющей объединение частных воль. Поэтому главным носителем «воли» объявляется народ, признание высшей власти которого закрепляется в понятии «суверенитета». На основе «общей воли»
Ж. - Ж. Руссо [11] возникло распространенное в современном французском праве понятие «общий интерес» (interêt général). Именно данная категория, означающая, что власть осуществляется в интересах народа в целом, а не отдельных лиц, признается законным основанием любой деятельности публичной власти» [12].

Эти идеи близки советским представлениям о полновластии народа, воплощавшимся там еще более последовательно. М. А. Митюков указывает, что «идеологической ...причиной невосприятия судебного конституционного надзора явилась трактовка этого института как учрежденного под влиянием буржуазной теории разделения властей» [13, С. 160-161]. Данная теория представлялась недопустимой, поскольку предполагала ограничение полновластия народа: «советская система отказывается от принципа разделения властей, так как в ней полностью отсутствуют его главные мотивы: страх перед народом и его тиранией» [14, С. 305].

Изложенные воззрения существенно отличаются от исходного понимания конституционализма, которые К. В. Арановский раскрывает следующим образом: «...в конституционной традиции подразумевается человек в качестве основы общества, а не общество, создающее индивидов. Эта подробность расставляет ударения в понимании отношений человека к обществу. У народа, если он производное от человека, нет оснований притязать на прочное господство над личностью. Общество, как и его публичная власть, не могут иметь собственных нужд, кроме нужд отдельных лиц в их взаимодействии, соперничестве и других сочетаниях» [15, С. 244-245]. Такое понимание не оставляет места для всеобщей воли как существующей помимо воли отдельных граждан. В то же время, подобные представления позволяют обосновать приоритет прав человека, ведь данная категория, также как и общий интерес, в значительной степени основана на ценностных представлениях. Исследователи указывают на то, что они «являются не только правовыми, но и важнейшими моральными категориями» [16, С. 15]. Поэтому, изучая данное понятие с точки зрения права, также необходимо учитывать этот факт, как и то, что «даже с аксиологической точки зрения эти ценности являются спорными» $[17$, С. 89$]$ и признаны не повсеместно.

Нужно «различать знание и оценочное суждение... видеть истину, отраженную в фактах» [10, С. 277], для чего важно преодолеть представления о рассматриваемом правовом институте, как имеющем безусловную ценность, поскольку такие представления не позволяют в полной мере составить представления о трудностях, сопровождающих распространение этого института. 
Поэтому при анализе подобных институтов интересно использовать аксиологический подход.

Отрицание буржуазных конституционных теорий в Советском союзе является общеизвестным фактом. Но и во Франции эти идеи принимались с поправками: «в Континентальной Европе американские идеи конституционализма были недопоняты и искажены. Сущность американского конституционализма заключалась в ограничении любой власти, включая суверенную власть народа, представленную законодательным органом. . . Французская Декларация прав и свобод 1789 г., напротив, способствовала усилению легислатуры (статья 6 «Закон является выражением общей воли»). Так, французская конституционная история начинается с идеи о суверенитете народа, выраженном в его воле, которая оформляется законодательным органом» [18, С. 54.], - пишет профессор А. Бланкенагель.

Таким образом, и всеобщая воля, и права человека являются ценностями, и каждая из них претендует на приоритет. Основываясь на представлениях о первичности человека по отношению к обществу, логично стремиться к установлению как можно более значимых ограничений власти, от кого бы она ни исходила, в пользу индивида. В то же время, если мы признаем, что общественные интересы не сводятся к сумме личных [19, С. 11.], что человек - неотъемлемая часть народа, то их противопоставление и утверждение приоритета интересов личности теряет смысл, потому что общий интерес является одновременно в какой-то степени интересом каждого человека, пусть неочевидным и не осознаваемым им самим. В таком случае речь не может идти о конфликте полностью противопоставленных друг другу интересов, а о конфликте более конкретного интереса с тем, который имеет значение лишь в отдаленной перспективе. Забота о благе самой личности вовсе не требует непременного утверждения первого из них.

Как пишет А. Мишель, «индивидуалисты XVIII века ...не знали коренной противоположности интересов индивида и государства. Французская революция последовательно применяла и крайний индивидуализм, и крайнюю государственность, не замечая в этом и тени противоречия. Людям того времени казалось так же естественным провозглашать права индивидуума, как и пользоваться авторитетом государства для признания и освящения этих прав» [20, С. 354]. Да и сам А. Мишель критикует современный индивидуализм и либерализм за то, что равенство приносится ими в жертву свободе, когда «крайним и логическим следствием такого понимания индивидуализма является... почти полное освящение всех фактических неравенств между людьми» [20, С. 354]. Распространенное во Франции понятие «общий интерес» понимается как выражающее «приверженность республике (то есть сильному, протекционистскому государству) и отказ подчиниться разрушающему социальные связи и по существу антиэгалитарному ультралиберализму» [21].

Конкретный контроль, который осуществляется «в случае заявления одной из сторон о неконституционности закона...т. е. не систематически, а разово» [22, C. 23], при том, что «заявители склонны видеть только нарушения со стороны государства» [23, С. 30], неизбежно смещает ориентиры, которыми руководствуется орган конституционного контроля. Он корректирует законодательство с целью его введения в сферу правоприменения для разрешения спора, который и привел гражданина в орган конституционного контроля. Отсюда необходим поиск компромисса.

Конституционный Суд России уже давно осуществляет проверку конституционности законов по обращениям граждан, стремясь в каждом случае найти баланс между частным и общим (публичным) интересами. Впрочем, с точки зрения значимости защиты прав человека, как функции Конституционного Суда, интересно рассмотреть новую редакцию статьи 43 Федерального конституционного закона «О Конституционном Суде» [24], в соответствии с которой возможно обжалование отмененных или утративших силу норм, которые продолжают применяться к правоотношениям, возникшим в период его действия. Тем самым была расширена возможность проверки конституционности утративших силу актов, ведь ранее такие акты рассматривались, только если они действовали на момент принятия обращения к рассмотрению.

Новая редакция названной статьи 43 исходит из того, что акты, пусть и отмененные, в некоторых случаях продолжают применяться на практике, как будто они действующие. Поэтому целью поверки конституционности таких «не действующих, но применяемых» актов является прекращение их применения в случае признания неконституционными и запрет на будущее вводить в законодательство подобные нормы. Изменившееся регулирование расширяет возможности органов конституционного контроля по защите прав граждан.

Можно выделить две основные цели, на которые направлен конституционный контроль по обращениям граждан: выявление и отмена неконституционных положений и защита прав заявителя. Целью проверки конституционности таких актов не может быть устранение неконституционных положений, поскольку они все равно не действуют. Поэтому можно предположить, 


\section{Право и политика 4 (184) 2015}

что данный процесс является в чистом виде способом защиты прав заявителя, хотя, конечно, следует учитывать, что такие решения также являются ориентиром для законодателя, устанавливая неконституционность определенных вариантов правового регулирования.

Разумеется, усиление защиты конституционных прав не обязательно осуществляется в ущерб общему интересу. Сама категория прав и свобод человека, являющаяся порождением индивидуалистической философии, изменилась с появлением в XX в. социальных прав, которые французские юристы признают одной из составляющих общего интереса [25]. Данные концепции в известной степени противоречат друг другу, в частности, в том, что касается обязанностей государства: обеспечение максимальной свободы граждан или опека над ними. «С провозглашением некоторых положительных прав (каковыми являются социальные права - М. К.) вмешательство в рыночные процессы превращается в конституционную обязанность правительства» [26, С. 44], - считает К. Санстейн.

Французский исследователь Д. де Лямот видит отличие стран континентальной Европы от англо-саксонских в ограничении законодателем свобод в пользу социальных прав [27]. С этим связано, в том числе, неоднозначное отношение к социальным правам, о котором упоминают, например, Н. С. Бондарь [28, С. 216-225], К. Л. Шеппели [29, С.52], и в силу которого они «не признаются неотъемлемой частью основных прав» [30, С.31].

Следовательно, понятие права и свободы человека отражает не лишенное противоречий сочетание «индивидуалистической философии XVIII в. и социальной XX в.» [31, C. 41]. Во Франции это сочетание выражено наглядно в «блоке конституционности», объединившем Декларацию прав и свобод человека и гражданина 1789 г. с Преамбулой Конституции 1946 г. (Хотя необходимость закрепления социальных прав обсуждалась создателями конституции уже в 1789-1793 гг.. [32]) Поэтому, даже если конституционная норма формулируется как утверждение права, она может защищать общий интерес.

Анализ решений Конституционного совета и Конституционного Суда показывает, что вряд ли они отдают предпочтение индивидуалистической концепции. Их нельзя назвать арбитром в споре между гражданином и властью, скорее контролером качества законов, в том числе с точки зрения учета в них прав человека. Данные органы не претендуют на решение принципиальных вопросов, в особенности в том, что связано с изменением этических стандартов. Очень показательно рассмотрение Конституционным советом вопроса о допустимости однополых браков. В решении от 17 мая
2013 г. [33], принятом в рамках последующего контроля, он признал, что запрет подобных браков не нарушает прав человека. Позже, был принят закон, отменяющий этот запрет. Он также был направлен на рассмотрение Конституционного совета, но уже в порядке предварительного контроля и был признан конституционным. По сути, Конституционный совет показал, что разрешение вопросов такого уровня связано с принципиальным выбором нации и, потому, не может разрешаться судом, а только парламентом. Отсюда, возможность заключения однополых браков не является естественным правом, а зависит от усмотрения парламента: как бы он не решил этот вопрос, он не нарушит Конституцию. Другим примером этического вопроса, оставленного Конституционным советом на усмотрение парламента, является решение от 30 сентября 2011 г. [34], в котором проверялась конституционность запрета взятия биологических проб для установления родства у усопших. Подтвердив конституционность оспариваемых положений, Конституционный совет обосновал свой вывод тем, что законодатель вправе устанавливать ограничения, призванные обеспечить должное почтение к усопшим.

Конституционный совет корректирует деятельность законодателя в рамках заданных самим же законодателем пределов. Ведь, когда Конституционный совет, например, признает норму неконституционной в связи с тем, что в ней не обеспечена в достаточной степени возможность для судьи варьировать наказание в зависимости от обстоятельств [35], или в связи с тем, что она ограничивает полномочия территориальных коллективов [36], он говорит о правах, которые признает и даже сам защищает в других своих актах Парламент. Речь идет лишь о степени защиты.

Аналогичную позицию занимает и Конституционный Суд России, когда, признавая положения закона соответствующими конституции, указывает, что «этим не исключается право федерального законодателя ... предусмотреть возможность иного правового регулирования» [37]. Как пишет Н. С. Бондарь, «выбор конкретной модели не только связан с содержанием действующего в данном государстве конституционного регулирования, но и в значительной мере определяется принципами правовой, в том числе судебно-правовой, политики, а потому, очевидно, не может быть осуществлен как таковой органом конституционного правосудия, решающим исключительно вопросы права; в своей основе это функция национального законодателя, призванного находить не только не противоречащие Конституции, но и политически, социально-экономически, нравственно-этически целесообразные правовые решения» [38]. 
Данную мысль подтверждает и то, что, по мнению исследователей, в задачу Конституционного совета входит обеспечение качества законов [39, С. 63-68]. Ведь такая задача предполагает, что орган конституционного контроля не столько оценивает политику парламента, сколько стремится помочь в осуществлении это политики.

Наиболее показательным примером является решение от 5 августа 2011 г. [40], в котором Конституционный совет, согласившись с Парламентом по сути, указал, что тот неправильно мотивировал свой выбор. В этом деле оспаривалась конституционность статьи 2 закона от 14 июля 1819 г., устанавливающей приоритетное положение наследника-француза в отношении имущества, находящегося на территории Франции. Конституционный совет счел, что разницу в правовом регулировании можно было обосновать приоритетным положением наследника-иностранца по иностранному законодательству, а закон просто предоставляет преимущество французу, что противоречит принципу равенства перед законом.

На обеспечение качества закона направлены, в частности, решения, в которых указывается на недостаточность существующего законодательного регулирования, например, на то, что законом закреплены не все признаки состава правонарушения $[41,42]$ или не дано определение используемого понятия (в решении от 1 августа 2013 г. [43] проверялась конституционность первого абзаца статьи L. 442-9 Трудового кодекса, в которой использовался термин «публичное предприятие», смысл которого не был разъяснен), на противоречие между разными статьями закона (например, из статьи 5 Федерального закона «Об обязательном страховании гражданской ответственности владельцев транспортных средств» следовало, что правительство определяет условия, на которых заключается договор обязательно- го страхования, тогда как другие положения закона не закрепляли за правительством такого полномочия [44]).

Российские исследователи также не считают конституционное судопроизводство способом защиты исключительно частных интересов. Как пишет Н. М. Голик, «стороны в Конституционном Суде отстаивают не только свои интересы, но и публичные интересы, заключающиеся в суждении о неконституционности закона» [45, С. 9].

Орган конституционного контроля, очевидно, не может не учитывать «юридических и неюридических ограничений, которые влияют на него и неявно присутствуют в сделанном выборе» [46, С. 141], в том числе понятие «общий интерес», понимаемое как основание для ограничения прав и свобод. Приведенные выше примеры можно рассматривать как свидетельство того, что Конституционный совет и Конституционный Суд стремятся сбалансировать предоставление гражданам права на обращение с вопросом о конституционности задевающего их закона и необходимость защиты общего интереса. Конечно, оптимальный баланс определяется по-разному приверженцами либерального подхода, предполагающего максимальную свободу граждан и минимальное регулирование их жизнедеятельности со стороны государства, и этатистского подхода, требующего расширения полномочий государства для обеспечения социальной справедливости и решения общегосударственных задач.

Таким образом, ценностные основания конституционного контроля правовых актов по обращениям граждан в Конституционном совете Франции и Конституционном Суде России, при всем различии соответствующих процедур в данных странах, схожи. Они нацелены на согласование разных групп социальных интересов на основе конституционных положений при приоритетной защите органами конституционного контроля прав и свобод граждан.

\section{Библиография:}

1. Андреева Г. Н. Конституционное право зарубежных стран: учебник. М.: Норма, 2009.

2. Несмеянова С. Э. Конституционный судебный контроль в Российской Федерации: проблемы теории и практики. Екатеринбург: Издательство УрГЮА, 2004.

3. Хабриева Т. Я., Чиркин В. Е. Теория современной конституции. М.: Норма, 2005.

4. Dutheillet de Lamothe O. Les methods de travail du conseil constitutionnel. URL : http://www.conseil-constitutionnel.fr/conseilconstitutionnel / root / bank mm / pdf / Conseil / 2007071 6Dutheillet.pdf (дата обращения - 14 февраля 2015 г.)

5. Брежнев О. В. Институт конституционной жалобы в субъектах России: нормативные модели и практика их реализации // Конституционное и муниципальное право. 2013. N 9.

6. François B. La place du Conseil constitutionnel dans le système politique de la Ve république // Le Conseil constitutionnel a 40 ans. Paris: LGDJ, 1999.

7. Le Pourhiet A. M. La confusion des arguments // Constitutions. 2010. № 3.

8. Карпенко К. В. Институт последующего (конкретного) конституционного контроля во Франции // Журнал зарубежного законодательства и сравнительного правоведения. 2013. №5.

9. Керимов А. Д. Выражает ли парламент всеобщую волю? // Право и политика. 2003. № 6.

10. Вебер М. «Объективность» социально-научного и социально-политического знания // Избранное: протестантская этика и дух капитализма. М., СПб.: Центр гуманитарных инициатив», 2013. 


\section{Право и политика 4 (184) 2015}

11. Sainte Rose M. J. L'intéret général et le juge. URL: http://www.conseil-constitutionnel.fr/conseil-constitutionnel/root/bankmm/ pdf/Conseil/sainterose.pdf (дата обращения - 14 февраля 2015 г.)

12. Lenoir N. L'interêt général, norme constitutionnelle ? URL: http://www.conseil-constitutionnel.fr/conseil-constitutionnel/root/ bank mm/pdf/Conseil/lenoir.pdf (дата обращения - 14 февраля 2015 г.)

13. Митюков М. А. Судебный конституционный надзор 1924-1933 гг.: вопросы истории, теории и практики М.: Формула права, 2005.

14. Левин И. Д. Современная буржуазная наука государственного права. М.: Издательство АН СССР, 1960.

15. Арановский К. В. Конституционная традиция в российской среде. СПб.: Издательство «Юридический центр Пресс», 2003.

16. Цыбулевская О. И. Нравственные основания современного российского права // Право и политика. 2004 . №4.

17. Шайо А. Универсальные права, миссионеры, обращенные и местные дикари // Конституционное право: Восточноевропейское обозрение. 1998. №2.

18. Бланкенагель А. О скрытой пользе сравнительного правоведения и сравнительного конституционного права // Конституционное право: восточноевропейское обозрение. 2004. №3.

19. Ефстифеев Д. М. Конституционно-правовые интересы личности в России (теоретико-правовой аспект): автореф. дис... канд. юрид. наук. - Екатеринбург, 2007.

20. Мишель А. Идея государства: критический опыт истории социальных и политических теорий во Франции со времен революции. М.: Издательский дом «Территория будущего», 2008.

21. Merland G. L'intérêt général dans la jurisprudence du Conseil constitutionnel.URL: http://www.conseil-constitutionnel.fr/conseilconstitutionnel /root/bank_mm /pdf/Conseil / merland.pdf (дата обращения - 28 февраля 2015 г.)

22. Остапович И. Ю. Специализированный конституционный контроль и надзор // Российский юридический журнал. 2008. № 3 .

23. Кальяк А. М. Логика конституционного правосудия в системе институтов демократии // Конституционное и муниципальное право. 2012. № 8.

24. Федеральный конституционный закон «О Конституционном Суде Российской Федерации» от 21 июля 1994 N 1-ФКЗ в редакции от 4 июля 2014 г. // СПС «Консультант плюс».

25. Sauvé J. - M. Le droit social, une œuvre collective. URL: http://www.conseil-etat.fr/fr/discours-et-interventions/la-place-despartenaires-sociaux-dans-lelaboration-des-reformes-kpv.html (дата обращения - 28 февраля 2015 г.)

26. Санстейн К. Отрицательные качества положительных прав // Конституционное право: восточноевропейское обозрение. 1993. № 1 .

27. Dutheillet de Lamothe O. Les normes constitutionnelles en matière sociale // Cahiers du Conseil constitutionnel. $2010 . \mathrm{n}^{\circ} 29$. URL: http://www.conseil-constitutionnel.fr/conseil-constitutionnel/francais/nouveaux-cahiers-du-conseil/cahier-n-29/les-normesconstitutionnelles-en-matiere-sociale.52733.html (дата обращения - 28 февраля 2015 г.)

28. Бондарь Н. С. Конституционный императив социальных прав (о практике Конституционного Суда России по социальной защите граждан) // Конституционное право: Восточноевропейское обозрение. 2002. №2.

29. Шеппели К. Л. Защита социальных прав с точки зрения реальной политики // Конституционное право: Восточноевропейское обозрение. 2003. №1.

30. Невинский В. В. Гражданин и основополагающие принципы конституции Федеративной Республики Германия: дис... докт. юрид. наук. - Екатеринбург, 1994.

31. Люшер Ф. Конституционная защита прав и свобод личности; пер. с франц. М.: Прогресс, 1993.

32. Lancelot A. Où il est question du bonheur au sommet de l'État // Cahiers du Conseil constitutionnel 2009. $\mathrm{n}^{\circ} 25$. URL: http:// www.conseil-constitutionnel.fr/conseil-constitutionnel / francais / nou veaux-cahiers-du-conseil/cahier-n-25/ou-il-est-questiondu-bonheur-au-sommet-de-1-etat.51697.html (дата обращения - 14 февраля 2015 г.) 32. Gay L. La notion de " droits-créances " à l'épreuve du contrôle de constitutionnalité // Cahiers du Conseil constitutionnel. 2004. n 16. URL: http://www.conseilconstitutionnel.fr/conseil-constitutionnel/francais/nouveaux-cahiers-du-con seil/cahier-n-16/la-notion-de-droits-creances-a-1epreuve-du-controle-de-constitutionnalite. 519 82.html(дата обращения - 14 февраля 2015 г.)

33. Décision $n^{\circ}$ 2013-669 DC du 17 mai 2013 // JORF du 18 mai 2013 page 8281, texte $\mathrm{n}^{\circ} 10$.

34. Décision $n^{\circ}$ 2011-173 QPC du 30 septembre 2011 // JORF du ler octobre 2011, P. 16528.

35. Décision $n^{\circ}$ 2010-6/7 QPC du 11 juin 2010 // JORF du 12 juin 2010, P. 10849.

36. Décision $n^{\circ}$ 2011-146 QPC du 08 juillet 2011 // JORF du 9 juillet 2011, P. 11978.

37. Постановление Конституционного Суда РФ от 08.12.2009 N 19-П // С3 РФ, 14.12.2009, N 50, ст. 6145.

38. Постановление Конституционного Суда РФ от 23.01.2007 N 1-П // СЗ РФ, 05.02.2007, N 6, ст. 828. Мнение Н. С. Бондаря.

39. Champell-Desplats V. N'est pas normatif qui peut. L'exigence de normativité dans la jurisprudence du Conseil Constitutionnel // Les Cahiers du Conseil constitutionnel. 2006. №2.

40. Décision n ${ }^{\circ}$ 2011-159 QPC du 05 août 2011 // JORF du 6 août 2011, P. 13478.

41. Постановление Конституционного Суда РФ от 17.06.2004 N 12-П // СЗ РФ, 05.07.2004, N 27, ст. 2803.

42. Décision $n^{\circ}$ 2012-240 QPC du 04 mai $2012 / /$ Journal officiel du 5 mai 2012, p. 8015.

43. Décision $n^{\circ}$ 2013-336 QPC du 01 août 2013 // JORF du 4 août 2013 page 13317.

44. Постановление Конституционного Суда РФ от 31.05.2005 N 6-П // СЗ РФ, 06.06.2005, N 23, ст. 2311.

45. Голик Н. М. Конституционная жалоба-гарантия защиты прав и свобод граждан в практике конституционного правосудия России :автореф. дис...канд. юрид. наук. - М., 2008. 
46. Gohesel Le Bihan V. Le contrôle de proportionnalité exercé par le Conseil constitutionnel // Les Cahiers du Conseil constitutionnel. 2007. № 22 .

47. Л.В. Максимов Возможно ли рациональное обоснование морали? // Философия и культура. - 2011. - 10. - С. 76-92.

\section{References (transliterated):}

1. Andreeva G. N. Konstitutsionnoe pravo zarubezhnykh stran: uchebnik. M.: Norma, 2009.

2. Nesmeyanova S. E. Konstitutsionnyi sudebnyi kontrol' v Rossiiskoi Federatsii: problemy teorii i praktiki. Ekaterinburg: Izdatel'stvo UrGYuA, 2004.

3. Khabrieva T. Ya., Chirkin V. E. Teoriya sovremennoi konstitutsii. M.: Norma, 2005.

4. Dutheillet de Lamothe O. Les methods de travail du conseil constitutionnel. URL : http://www.conseil-constitutionnel.fr/conseilconstitutionnel / root / bank_ mm / pdf / Conseil / 2007071 6Dutheillet.pdf (data obrashcheniya - 14 fevralya 2015 g.)

5. Brezhnev O. V. Institut konstitutsionnoi zhaloby v sub"ektakh Rossii: normativnye modeli i praktika ikh realizatsii // Konstitutsionnoe i munitsipal'noe pravo. 2013. N 9.

6. François B. La place du Conseil constitutionnel dans le système politique de la Ve république // Le Conseil constitutionnel a 40 ans. Paris: LGDJ, 1999.

7. Le Pourhiet A. M. La confusion des arguments // Constitutions. 2010. № 3.

8. Karpenko K. V. Institut posleduyushchego (konkretnogo) konstitutsionnogo kontrolya vo Frantsii // Zhurnal zarubezhnogo zakonodatel'stva i sravnitel'nogo pravovedeniya. 2013. №5.

9. Kerimov A. D. Vyrazhaet li parlament vseobshchuyu volyu? // Pravo i politika. 2003. № 6.

10. Veber M. «Ob"ektivnost'» sotsial'no-nauchnogo i sotsial'no-politicheskogo znaniya // Izbrannoe: protestantskaya etika i dukh kapitalizma. M., SPb.: Tsentr gumanitarnykh initsiativ», 2013.

11. Sainte Rose M. J. L'intéret général et le juge. URL: http://www.conseil-constitutionnel.fr/conseil-constitutionnel/root/bankmm/ pdf/Conseil/sainterose.pdf (data obrashcheniya - 14 fevralya 2015 g.)

12. Lenoir N. L'interêt général, norme constitutionnelle ? URL: http://www.conseil-constitutionnel.fr/conseil-constitutionnel/root/ bank mm/pdf/Conseil/lenoir.pdf (data obrashcheniya - 14 fevralya 2015 g.)

13. Mityukov M. A. Sudebnyi konstitutsionnyi nadzor 1924-1933 gg.: voprosy istorii, teorii i praktiki M.: Formula prava, 2005.

14. Levin I. D. Sovremennaya burzhuaznaya nauka gosudarstvennogo prava. M.: Izdatel'stvo AN SSSR, 1960.

15. Aranovskii K. V. Konstitutsionnaya traditsiya v rossiiskoi srede. SPb.: Izdatel'stvo «Yuridicheskii tsentr Press», 2003.

16. Tsybulevskaya O. I. Nravstvennye osnovaniya sovremennogo rossiiskogo prava // Pravo i politika. 2004 . №4.

17. Shaio A. Universal'nye prava, missionery, obrashchennye i mestnye dikari // Konstitutsionnoe pravo: Vostochnoevropeiskoe obozrenie. 1998. №2.

18. Blankenagel' A. O skrytoi pol'ze sravnitel'nogo pravovedeniya i sravnitel'nogo konstitutsionnogo prava // Konstitutsionnoe pravo: vostochnoevropeiskoe obozrenie. 2004. №3.

19. Efstifeev D. M. Konstitutsionno-pravovye interesy lichnosti v Rossii (teoretiko-pravovoi aspekt): avtoref. dis...kand. yurid. nauk. - Ekaterinburg, 2007.

20. Mishel' A. Ideya gosudarstva: kriticheskii opyt istorii sotsial'nykh i politicheskikh teorii vo Frantsii so vremen revolyutsii. M.: Izdatel'skii dom «Territoriya budushchego», 2008.

21. Merland G. L'intérêt général dans la jurisprudence du Sonseil constitutionnel.URL: http://www.conseil-constitutionnel.fr/conseilconstitutionnel /root/bank_mm /pdf/Conseil / merland.pdf (data obrashcheniya - 28 fevralya 2015 g.)

22. Ostapovich I. Yu. Spetsializirovannyi konstitutsionnyi kontrol' i nadzor // Rossiiskii yuridicheskii zhurnal. 2008 . № 3.

23. Kal'yak A. M. Logika konstitutsionnogo pravosudiya v sisteme institutov demokratii // Konstitutsionnoe i munitsipal'noe pravo. 2012. № 8.

24. Sauvé J. - M. Le droit social, une œuvre collective. URL: http://www.conseil-etat.fr/fr/discours-et-interventions/la-place-despartenaires-sociaux-dans-lelaboration-des-reformes-kpv.html (data obrashcheniya - 28 fevralya $2015 \mathrm{~g}$.)

25. Sanstein K. Otritsatel'nye kachestva polozhitel'nykh prav // Konstitutsionnoe pravo: vostochnoevropeiskoe obozrenie. 1993 . № 1.

26. Dutheillet de Lamothe O. Les normes constitutionnelles en matière sociale // Cahiers du Conseil constitutionnel. $2010 . \mathrm{n}^{\circ} 29$. URL: http://www.conseil-constitutionnel.fr/conseil-constitutionnel/francais/nouveaux-cahiers-du-conseil/cahier-n-29/les-normesconstitutionnelles-en-matiere-sociale.52733.html (data obrashcheniya - 28 fevralya 2015 g.)

27. Bondar' N. S. Konstitutsionnyi imperativ sotsial'nykh prav (o praktike Konstitutsionnogo Suda Rossii po sotsial'noi zashchite grazhdan) // Konstitutsionnoe pravo: Vostochnoevropeiskoe obozrenie. 2002. №2.

28. Sheppeli K. L. Zashchita sotsial'nykh prav s tochki zreniya real'noi politiki // Konstitutsionnoe pravo: Vostochnoevropeiskoe obozrenie. 2003. №1.

29. Nevinskii V. V. Grazhdanin i osnovopolagayushchie printsipy konstitutsii Federativnoi Respubliki Germaniya: dis...dokt. yurid. nauk. - Ekaterinburg, 1994.

30. Lyusher F. Konstitutsionnaya zashchita prav i svobod lichnosti; per. s frants. M.: Progress, 1993.

31. Lancelot A. Où il est question du bonheur au sommet de l'État // Cahiers du Conseil constitutionnel 2009. $n^{\circ} 25$. URL: http:// www.conseil-constitutionnel.fr/conseil-constitutionnel / francais / nou veaux-cahiers-du-conseil/cahier-n-25/ou-il-est-questiondu-bonheur-au-sommet-de-1-etat.51697.html (data obrashcheniya - 14 fevralya 2015 g.) 32. Gay L. La notion de " droits-créances 
DOI: $10.7256 / 1811-9018.2015 .4 .14689$

При цитировании этой статьи сноска на доі обязательна

\section{Право и политика $4(184) \cdot 2015$}

" à l'épreuve du contrôle de constitutionnalité // Cahiers du Conseil constitutionnel. 2004. n 16. URL: http://www.conseilconstitutionnel.fr/conseil-constitutionnel/francais/nouveaux-cahiers-du-con seil/cahier-n-16/la-notion-de-droits-creances-a-1epreuve-du-controle-de-constitutionnalite. 519 82.html(data obrashcheniya - 14 fevralya 2015 g.)

32. Champell-Desplats V. N'est pas normatif qui peut. L'exigence de normativité dans la jurisprudence du Conseil Constitutionnel // Les Cahiers du Conseil constitutionnel. 2006. №2.

33. Golik N. M. Konstitutsionnaya zhaloba-garantiya zashchity prav i svobod grazhdan v praktike konstitutsionnogo pravosudiya Rossii :avtoref. dis...kand. yurid. nauk. - M., 2008.

34. Gohesel Le Bihan V. Le contrôle de proportionnalité exercé par le Conseil constitutionnel // Les Cahiers du Conseil constitutionnel. 2007. № 22 .

35. L.V. Maksimov Vozmozhno li ratsional'noe obosnovanie morali? // Filosofiya i kul'tura. - 2011. - 10. - C. 76-92. 